\title{
Wielorakie aspekty piękna i brzydoty w architekturze
}

\begin{abstract}
Recenzja:
Bogusław Szuba, Tomasz Drewniak, red. Piękno w architekturze: tradycja i współczesność. Koncepcje. Nysa: Oficyna Wydawnicza PWSZ w Nysie, 2018, ss. 246; Bogusław Szuba, Tomasz Drewniak, red. Piękno w architekturze: tradycja $i$ współczesność. Realizacje. Nysa: Oficyna Wydawnicza PWSZ w Nysie, 2018, ss. 261; Bogusław Szuba, Tomasz Drewniak, eds. Beauty in architecture: tradition and contemporary trends. Concepts. Translated by AGIT Translations. Nysa: Oficyna Wydawnicza PWSZ w Nysie, 2018, ss. 231; Bogusław Szuba, Tomasz Drewniak, eds. Beauty in architecture: tradition and contemporary trends. Implementations. Translated by AGIT Translations. Nysa: Oficyna Wydawnicza PWSZ w Nysie, 2018, ss. 247.
\end{abstract}

\section{Henryk Benisz}

\section{https://orcid.org/0000-0001-5449-0760}

Pokłosiem I Międzynarodowej Interdyscyplinarnej Konferencji NaukowoTechnicznej, która odbyła się w dniach 6-7 czerwca 2018 roku w Państwowej Wyższej Szkoły Zawodowej w Nysie, są cztery książki o pięknie w architekturze: dwie w języku polskim i dwie w języku angielskim. Obie edycje językowe zawierają bardzo interesujące opracowania poświęcone teorii (Koncepcje) i praktyce (Realizacje) architektonicznej. Każdy tom rozpoczyna się merytorycznym wprowadzeniem Tomasza Drewniaka i Bogusława Szuby, prezentującym ideę główną tego przedsięwzięcia naukowego i ułatwiającym poruszanie się w przestrzeni tekstualnej poszczególnych opracowań.

HENRYK BENISZ, prof. dr. hab., Instytut Filozofii, Uniwersytet Opolski; adres do korespondencji: Instytut Filozofii Uniwersytetu Opolskiego, ul. Katowicka 89, 45-061 Opole; e-mail: benisz@uni.opole.pl 
W części „koncepcyjnej” przykuwa uwagę tekst Wojciecha Kosińskiego Czy piękno ocali świat? Filozofia i twórczość. Znajdujemy w nim oryginalną próbę sklasyfikowania dotychczasowych stylów i epok w sztuce budowania. Jedne z nich charakteryzują się racjonalnością, regularnością i artystyczną skromnością, inne zaś irracjonalnością, nieregularnością i artystycznym „rozpasaniem”. Ilustruje to krzywa, której najniższe punkty odpowiadają m.in. klasycznemu antykowi, romanizmowi, renesansowi, klasycyzmowi, modernizmowi i minimalizmowi, natomiast najwyższe punkty hellenizmowi, bizantynizmowi, gotykowi, barokowi, postmodernizmowi i dekonstruktywizmowi. Autor, inspirując się poglądami Fryderyka Nietzschego, zasadnie kojarzy pierwsze z nich z tendencją apollińską, a drugie $z$ tendencją dionizyjską. Ciekawe jest też to, że współczesność, będąca trzecią odsłoną modernizmu, naznaczona jest jednoczesnością panowania minimalizmu i (dekonstruktywistycznego) maksymalizmu. Zdaniem Kosińskiego, ten swoisty dualizm estetyczny ma świadczyć o wewnętrznym bogactwie i różnorodności doznań dzisiejszych odbiorców sztuki. Jak mi się wydaje, mógłby on jednak również potwierdzać nieokreśloność epoki, w której aktualnie żyjemy, i niezdecydowanie ludzi, którzy już nie bardzo wiedzą, czym jest piękno i gdzie je można znaleźć. Tak czy inaczej, przyglądając się linii naprzemiennie pnącej się w górę i opadającej w dól, poczułem się dokładnie tak samo, jak na jednym z wykładów z moich czasów studenckich, kiedy to ceniony przeze mnie literaturoznawca, omawiając teorię René Welleka i Austina Warrena, narysował na tablicy sinusoidę. W moim odczuciu, mamy tu do czynienia z manifestującym się przekonaniem o konstytutywnej zmienności wszechrzeczy i niemożności ustalenia raz na zawsze stałych zasad porządkujących nasz świat - również w wymiarze twórczym, dotyczącym kreacji przedmiotowego piękna. Wprawdzie sam także podzielam to przekonanie, jednak nadal marzy mi się kanoniczne piękno, wieczne i niezmienne jak Parmenidesowy byt, będące nigdy nie dewaluującym się wzorcem i punktem odniesienia jak Platońskie idee. Może powinienem się wreszcie wyzbyć młodzieńczych fanaberii i estetycznie wydorośleć?...

Na szczęście tekst Bogusława Szuby Piękno i harmonia zasadą kształtowania otoczenia człowieka odbudowuje moją wiarą w trwałą ideę piękna - również ideę piękna w architekturze. Autor przede wszystkim zwraca uwagę na potrzebę istnienia harmonijnej relacji między środowiskiem przyrodniczym, społeczno-kulturowym i zbudowanym. Ona bowiem, choć trudno ją obiektywnie zmierzyć, świadczy o pięknie. Mierzyć, w ścisłym tego słowa znaczeniu, potrafimy tylko proporcje 
obiektów. Bardzo interesujące i pouczające jest doświadczenie przeprowadzone onegdaj przez Borissovlievitcha. Ten angielski etolog pokazał testowanym osobom dziesięć różnych prostokątów, z których mieli wybrać ich zdaniem najpiękniejszy. Większość z nich wybrała prostokąt o stosunku długości boków 21:34, co odpowiada tzw. złotemu podziałowi. Okazuje się, że dla naszego oka najbardziej piękne są obiekty odwzorowujące ów złoty podział. Z tego powodu w starożytności i w średniowieczu matematycy stali na straży boskiej proporcji (divina proportio). Tę zaś można odnaleźć już w otaczającym nas świecie przyrody. Nawet z pozoru tak prosty element przyrodniczy, jakim jest cząsteczka wody, opiera się na złotym podziale. Do tegoż podziału nawiązują również rośliny swym układem liści, podobnie jak kaktus swym układem brodawek. Jak wiadomo, dla artystów wzorcowo piękny stał się człowiek, o czym świadczą optymalne odległości między określonymi punktami ciała. W człowieku złoty podział manifestuje się jednak również w cyklu fal mózgowych i w genomie DNA. Dostrzec go można także w rezonansie magnetycznym spinów w kryształach niobanu kobaltu. Poznając przyrodę, dostrzegamy zawarte w niej prawidłowości i - tym samym - zawarte w niej naturalne piękno. Stąd wynika potrzeba harmonijnego współżycia z naturą, ufania jej i poszanowania jej praw. Architektura powinna się coraz szerzej otwierać na naturę i stosować do jej reguł. Gdy człowiek zinternalizuje odkrytą w przyrodzie harmonię bytu, odnajdzie też wewnętrzną równowagę i poczucie szczęścia. Szuba opowiada się za tym, że natura w swej przyrodniczej kreacji stara się w sposób doskonały wykorzystać przestrzeń. Dlaczego więc nie mielibyśmy uczyć się od przyrody sztuki budowania jako zagospodarowywania przestrzeni i... sztuki życia jako zagospodarowywania nas samych?

O szczególnym rodzaju sztuki życia mówi tekst Tomasza Drewniaka Piękno jako uobecnienie i afirmacja „bycia ku śmierci”: most - świątynia - chata. Jest to twórcze nawiązanie do ontologii fundamentalnej Martina Heideggera, rzucające więcej światła na problem bycia jako zamieszkiwania. Heidegger zauważył, że współczesny człowiek doświadcza w świecie bezdomności. Stara się on zatem na nowo zadomowić w świecie - tak, by żyć w prawdzie. Ludzkie życie jest byciem na drodze ku śmierci, jest swoistym przejściem. Jest więc także jakby mostem ku czemuś innemu. Most jako obiekt architektoniczny zawiera w sobie głęboką symbolikę egzystencjalną. Jego końce łączą osobne obszary, nadając sens całości życia, świata, bytu. Będąc na moście, człowiek funkcjonuje w układzie horyzontalnym 
i wertykalnym - ma za sobą już przebytą drogę i przed sobą jeszcze drogę do przejścia, ma pod sobą płynącą rzekę i nad sobą niebo z Bogiem, od którego jest jakoś zależny. Człowiek jest stale pomiędzy ludźmi i Bogiem oraz pomiędzy fragmentami przyrodniczego świata. Zwłaszcza zaś jest wśród ludzi i dla ludzi - jest na moście, by samemu być łączącym ludzi mostem. Podobnie świątynia łączy rozdzielone sfery sacrum i profanum, nieśmiertelnego Boga ze śmiertelnymi ludźmi. $\mathrm{W}$ niej dochodzi do zniesienia przeciwieństw, do scalenia bytu w uniwersum. W niej rozgrywa się prawdziwy dramat człowieczeństwa rozdartego między narodzinami a śmiercią, między dobrem a złem, między upadkiem a zbawieniem, między rozbiciem a pojednaniem. Świątynia jest miejscem religijnej inicjacji, następuje w niej połączenie drogi cielesnej z drogą duchową i dochodzi do wewnętrznej przemiany człowieka. W istocie, budowanie, mieszkanie i istnienie łączą się w jedną całość bycia człowiekiem. Z kolei dom łączy pokolenia (przodków z potomnymi), jest on też swoistym biegunem magnetycznym życia, jako że przyciąga i skłania do nieustannego powracania i do bycia u siebie i - w końcu - także do bycia sobą. Życie w domu przebiega w zgodzie z naturalnym, zapisanym w przyrodzie rytmem przemian. Zbiegają się w nim również cykle pracy i odpoczynku. Właściwie wszystko w naszym życiu kręci się wokół domu. Z tego powodu dom powinien być dobrze zaprojektowany i zbudowany. Jeżeli architekt dobrze wywiąże się ze swego zadania, to powstały za jego sprawą dom sam będzie nas potem budował i dawał poczucie zadomowienia. Wydaje się, że piękno w architekturze jest ściśle związane z egzystencjalnym pięknem osób żyjących w architektonicznych obiektach. Ontologia splata się tu z estetyką.

W tym kontekście bardzo wymowny jest tekst Tomasza Wagnera Antyestetyzm $w$ architekturze. Wybrane zagadnienia. Autor buduje jego narrację wychodząc od stwierdzenia, że niektórzy twórcy kwestionują kanony piękna, a nawet gloryfikują brzydotę. Całkiem świadomie przeciwstawiają się oni tradycji i klasycznym konwencjom. Widzimy to w wielu nurtach sztuki, takich jak modernizm, neomodernizm, minimalizm, konstruktywizm, puryzm czy brutalizm. Odnośnie tego ostatniego nurtu naszła mnie myśl, czy nie lepiej byłoby określać go mianem brutyzmu, wszak z potocznie rozumianym brutalizmem nie ma on nic wspólnego. Chodzi w nim głównie o wyzbycie się pięknego zewnętrza, mającego walory dekoracyjne, i wyeksponowanie surowego wnętrza (franc. brut = surowy), pozbawionego tychże walorów. Dla brutystów - jeśli wolno mi posłużyć się tym neolo- 
gizmem - architektura ma się zaczynać i kończyć surową fakturą/strukturą materiału budowlanego. Jak mniemam, goły, spękany beton jest dla nich upragnionym szczytem architektonicznej brzydoty. Wszelkie obiekty powinny być wolne od klasycznego piękna, stąd podczas projektowania architekci-antyestetycy unikają stosowania doskonałych proporcji. Ich misją jest tworzenie kompozycji kuriozalnie spiętrzonych i manierycznie zdeformowanych. Dopełnieniem antyestetycznego obiektu mogą być różne odpady, którymi okrasza się budynki, aby były jeszcze brzydsze.

Już Antonio Gaudi eksperymentował z wykorzystywaniem odpadów ceramicznych, ale dopiero w Polsce zastosowano metodę okładania fasad domów potłuczonymi naczyniami, uzyskując spektakularny efekt skrajnej brzydoty. Przykłady pokazane przez Wagnera i zaiste będące polskim ewenementem architektonicznym, mogą budzić uczucie obrzydzenia. Rodzi się jednak pytanie, czy jest to przejaw artystycznej prowokacji i chęci wstrząśnięcia odbiorcą tej nowej „sztuki”, czy też użyte materiały, dobrane odpowiednio do zasobności portfela właściciela obiektu, mają pełnić wyłącznie funkcję użytkową. Można sobie wyobrazić, choć z trudem, że ktoś obłożył potłuczonymi naczyniami fasadę budynku, aby ją ochronić przed zmiennymi warunkami atmosferycznymi i zarazem nieco poprawić parametry termiczne pomieszczeń. Takie rozwiązanie, mimo groteskowego wyglądu, jest - w pewnym sensie - bardzo skuteczne. Szeroko stosowane w drugiej połowie XX wieku płytki eternitowe trzeba do końca 2032 roku zdjąć i zutylizować, aby zawarty w nich azbest nie szkodził człowiekowi, natomiast ceramiczne skorupy mogą sobie wisieć in saecula saeculorum, ponieważ nie szkodzą nam, nie licząc ponoszonych przez nas strat w zakresie poczucia piękna. Atoli przyjemniej byłoby pomyśleć, że te potłuczone naczynia powstały podczas hucznego wesela albo burzliwego dojrzewania dziecka z ADHD. Wtedy umieszczenie ich na budynku stanowiłoby sentymentalną formę uwiecznienia bardzo ważnych wydarzeń egzystencjalnych z życia mieszkańców.

$\mathrm{Na}$ ogół różne straszydła architektoniczne powstają w wyniku doznanego przez twórcę przesytu otaczającym go pięknem. Skoro może zemdlić zbyt duża ilość skonsumowanych słodyczy, to u niektórych osobników może też powstać uczucie mdłości na widok wszechobecnych obiektów architektonicznych, które epatują otoczenie kanonicznym pięknem. W reakcji obronnej na to piękno tworzy się wtedy konstrukcje prowizoryczne, ubogie pod każdym względem i niepowta- 
rzalnie brzydkie. Bywają nawet ludzie tak bardzo spragnieni doznań antyestetycznych, że swój komfortowy dom stylizują na rozpadającą się lepiankę albo wiejską chatę, lub też czasowo przenoszą się ze swego ładnego i wygodnego mieszkania, by trochę pomieszkać w obskurnym więzieniu przerobionym na hotel. Nie da się wykluczyć, że człowiek z natury jest istotą wewnętrznie rozdartą i nieustannie miotającą się między skrajnymi tendencjami i rozwiązaniami. Tak jak Staś Wokulski w Lalce był targany skłonnościami romantycznymi i pozytywistycznymi, tak też inne osoby miotają się między pięknem a brzydotą, nie wiedząc, co ostatecznie wybrać i - tym samym - stają się wiecznie żywym i wiecznie deprymującym symbolem rozdartej sosny. Tak niezrównoważone osoby można łatwo omotać różnymi ideologiami, jak choćby skrajnie rozumianą architekturą ekologiczną.

O ile utrzymane w ryzach zdrowego rozsądku myślenie proekologiczne jest niewątpliwie słuszne, o tyle myślenie panekologiczne, $\mathrm{z}$ uporem kontestujące dobrodziejstwo cywilizacji i nowoczesnych technologii, jest pozbawione waloru słuszności. Czasem granice między powyższymi rodzajami myślenia zdają się zacierać. Jak tu bowiem ocenić tych, którzy, nie chcąc dodatkowo niszczyć środowiska naturalnego, adaptują do zamieszkania stare kontenery, wagony kolejowe, a nawet samoloty. Albo jak odnieść się do tych, których nie satysfakcjonuje upcykling (przetwarzanie podwyższające jakość zużytego materiału) i budują swoje domy z wykorzystaniem downcyklingu (przetwarzanie obniżające jakość materiału) albo pseudorecyklingu (przetwarzanie, w którym nie wiadomo o co chodzi). Dużo łatwiej pojąć zwolenników zwyczajnego recyklingu, którzy budują swe domostwa ze śmieci i tak oto lansują popkulturę zamieszkałych śmietników albo subnaturę, czyli stworzone ze śmieci nowe środowisko życia człowieka. Wagner zwraca uwagę na spektakularny przejaw budownictwa ekologicznego, jakim jest Europa Building - nowa siedziba Rady Europy w Brukseli, której fasadę wykonano ze starych i ponoć pięknych dębowych ram okiennych, wcześniej usuniętych $z$ innego obiektu przez ekipę budowlaną wykonującą tam remont i termomodernizację. Jeżeli taki przykład idzie z góry, to nie ma się co dziwić, że - jako ludzka populacja - stajemy się coraz bardziej niezrównoważeni i narażeni na ideowe wpływy różnej maści ekoterrorystów.

Wyrazem troski o zachowanie szeroko pojętej równowagi jest tekst Beaty Majerskiej-Pałubickiej Walory estetyczne zrównoważonej architektury. Autorka, nawiązując do poglądów Thomasa Maxa Fischera, Samuela Mockbee i innych architektów, opowiada się za zrównoważoną architekturą. To stanowisko respektuje 
ustalenia Rady Architektów Europy z 1999 roku, która chciałaby, aby architektura przetwarzała ideę $\mathrm{w}$ trwałą formę, a przy tym optymalnie łączyła walory otoczenia, trwałe materiały, niskie zużycie energii, potrzeby ekologiczne i potrzebę dopasowania kultury do natury (otoczenie). W gruncie rzeczy chodzi tu o to, aby powiązać, i przez to zrównoważyć, odpowiednią jakość życia z jakością środowiska zbudowanego i jakością środowiska przyrodniczego. Ponieważ projektowanie musi uwzględniać różne czynniki, architekturę trzeba pojmować holistycznie i multidyscyplinarnie. Przy tworzeniu projektów należy czerpać wzorce z przyrody (żywe struktury), jako że - zdaniem autorki - natura jest najlepszą nauczycielką. Zarazem jednak należy stosować innowacyjne technologie i posługiwać się narzędziami wspomagającymi proces projektowania. Mogę domniemywać, że skoro architektura zrównoważona powstaje w biurach architektonicznych przy współudziale wielu architektów, to jest wyrazem pewnego konsensusu, również estetycznego. Dzięki temu powinna pozytywnie oddziaływać na zmysły i ducha człowieka, a także dobrze się komponować z ekologicznym światem.

Majerska-Pałubicka podkreśla wysokie wymagania, jakie się stawia architektom. Ten zawód nie jest tylko jednym $z$ wielu sposobów na zarabianie pieniędzy czy samorealizację przez pracę, gdyż profesja architekta zalicza się do zawodów zaufania publicznego. Architekci mają do spełnienia pewną misję i powinni respektować lekarską zasadę primum non nocere. Obiektami zrealizowanymi zgodnie z zasadami architektury zrównoważonej są m.in. londyński wieżowiec Swiss Re Tower i pekiński Stadion Olimpijski. Przyglądając się im, można jednak mieć wątpliwości, czy faktycznie projektanci respektowali kanon Witruwiusza i ponadczasowe walory architektonicznego piękna. Obiekty te mogą się kojarzyć z architekturą śmieciową, z prowizorkami budowlanymi albo z konstrukcjami powstałymi na doraźną potrzebę. Oczywiście wiadomo, że niegdyś wieża Eiffla również powstała na potrzebę światowej wystawy w 1889 roku, a jednak nie rozebrano jej po dwudziestu latach i do dzisiaj jest niezwykle urokliwym symbolem Paryża, chętnie oglądanym i podziwianym przez turystów z całego świata. Wspomniane wcześniej przykłady architektury zrównoważonej chyba jednak nie mogą liczyć na tak oszałamiającą karierę. Mam nadzieję, że Autorka nie pogniewa się na mnie, gdy przyznam, że - mimo szczerych chęci sprostania jej życzeniom - chyba nie umiałbym pokochać tych obiektów za (rzekome) piękno i walory projektowe. Cóż, de gustibus non disputandum est... 
Pozostałe, również intersujące teksty w części „koncepcyjnej” to: Peter Schmid (Prakash) i Gabriela Pal-Schmid, Piękno schronienia zasadą kształtowania otoczenia człowieka; Piotr Stachurski, Porządek architektoniczny jako kanon piękna $w$ architekturze (na podstawie analizy „De architectura libri decem” Witruwiusza); Marco Lucchini, Zasada gry: Piękno jako dualizm pomiędzy rdzeniem konstrukcyjnym budowli a szatą dekoracyjną; Anna Kossak-Jagodzińska, Kanony piękna w architekturze a współczesne źródła inspiracji; Anna Nowak i Wiesław Rokicki, Wzorce bioniczne w poszukiwaniu piękna w architekturze i urbanistyce; Andrzej Jaworski, Redefinicja idei piękna w kontekście nowatorskich poszukiwań w sztuce na przełomie XIX i XX wieku; Sebastian Pniak, Strefy piesze przestrzenią doznań estetycznych związanych $z$ odczuwaniem piękna $w$ architekturze; Krystyna Strumiłło, Kanon piękna w architekturze betonowej.

W części „realizacyjnej” znajduje się m.in. tekst Jakuba Lewickiego W poszukiwaniu piękna i funkcjonalności. Konkurs na odbudowę rynku w Nysie. Można się z niego dowiedzieć, że Nysa - miasto, w którym zorganizowano konferencję była „śląskim Rzymem” mającym bogatą historię. W średniowieczu i okresie nowożytnym wzniesiono tu wiele ważnych obiektów sakralnych i świeckich. Do końca drugiej wojny światowej w Nysie było 6 zabytkowych kościołów i ponad 400 kamienic, jak też fortyfikacje miejskie. Przetrwawszy w dobrym stanie wiele stuleci i ostatnią zawieruchę wojenną, zaczęły ulegać zniszczeniu dopiero po 1945 roku. Nie licząc się z protestami lokalnych intelektualistów, rozbierano je i w ich miejsce stawiano nowe budynki, które wyrażały już nowego ducha czasu i spełniały kryteria bardziej użytkowe niż estetyczne. Tę bezduszną i - nie bójmy się użyć tego słowa - bezmyślną działalność włodarzy miejskich przetrwało tylko dwadzieścia kilka kamienic. Dopiero w latach 60. rozpisano konkurs na projekt urbanistyczno-architektoniczny nyskiego rynku, do którego stanęło kilka zespołów architektonicznych. Z przedstawionej przez Lewickiego charakterystyki tych projektów wynika, że bazowały na harmonijnym dopasowaniu obiektów, z poszanowaniem zabytkowej zabudowy historycznej. Niestety, nie tylko zwycięskiego, ale żadnego z tych projektów nie zrealizowano, a dokumentacja konkursu nawet nie zachowała się w archiwach. Jak widać, tradycyjne zasady budowania i klasyczna idea piękna nie pasowały do nowych, socjalistycznych idei politycznych. Wielka szkoda. Osobiście wydaje mi się jednak, że mimo tych negatywnych doświadczeń z powojennego okresu „błędów i wypaczeń”, Nysa wciąż jest uroczym miastem o niepowtarzalnym kolorycie i ciepło-przytulnych klimatach. 
Pozostałe, również intersujące teksty w części „realizacyjnej” to: Svitlana Topylko i Uliana Ivanochko, Tworzenie układu architektoniczno-planistycznego renesansowych miast galicyjskich z drugiej połowy XVI i XVII wieku; Agata Skórka, Co stanowiło o pięknie dawnych rynków polskich? Wybrane przykłady, Grażyna Lasek, Problematyka piękna $w$ dokumentach Kościoła katolickiego a praktyka architektury sakralnej - wybrane zagadnienia; Anita Staszewska-Furmanek, Tradycja i nowoczesność w obiektach teatralnych - dialog wartości dla tożsamości kulturowe; Piotr Patoczka, Czy Kęty są piękne?; Piotr Opałka, Re-aktywacja przestrzeni publicznych pogranicza polsko-czeskiego na przykładzie węzła kolejowego w Głuchołazach; Krzysztof Gasidło, Jak odkrywaliśmy piękno upadłych fabryk, Piotr Kuczia, W poszukiwaniu piękna miejsca pracy, Agata Pięt, Poszukiwanie piękna $w$ architekturze $d$ worców kolejowych na przykładzie wybranych realizacji; Jan Gancewski, Piękno w architekturze w aspekcie historii Prus krzyżackich. Aspekt funkcjonalny, Wiesław Rokicki i Ewelina Gawell, Strukturalizm współczesnych detali architektonicznych; Najmeh Hassas, Naturalne piękno perskich namiotów koczowniczych. Tradycja rękodzielnictwa; Hanna Michalak i Jerzy Su-

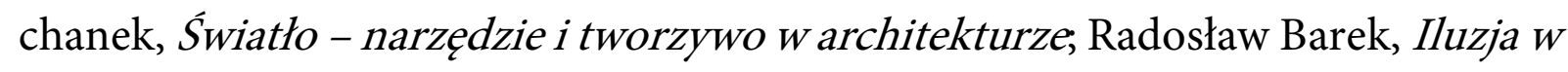
przestrzeni małych miast, Małgorzata Korpała, Piękno czy prawda - dylematy zakresu ingerencji na wybranych przykładach konserwacji polichromii ściennych.

Obecnie żyjemy w bardzo dziwnych czasach. Ministerstwo Nauki i Szkolnictwa Wyższego sfinansowało nyską konferencję i publikacje pokonferencyjne, zapewne uznając to przedsięwzięcie za wartościowe z naukowego punktu widzenia, jednak zarazem odmówiło mu jakiegokolwiek waloru naukowego, jako że - zgodnie z nowymi ustaleniami ministerialnymi - za publikacje w takich pracach zbiorowych nie dostaje się żadnych punktów. Po długim, iście filozoficznym namyśle nad materią trudnych do zrozumienia działań tegoż Ministerstwa doszedłem do konkluzji wykluczającej pozornie oczywistą sprzeczność. Otóż wydaje mi się, że analogicznie do bezcennych wytworów kultury materialnej bytują również bezcenne wytwory kultury duchowej, ufundowane na tych pierwszych wytworach. Inaczej mówiąc, jeżeli po jednej stronie mamy zabytki klasy zerowej, a do takich niejednokrotnie odwołują się architekci i znawcy sztuki, to - dla zachowania harmonii nie tylko architektonicznego piękna - po drugiej stronie powinny się pojawić publikacje klasy zerowej, korelujące z zabytkami klasy zerowej. Tak też się stało. Udostępnione polskiemu i zagranicznemu czytelnikowi opracowania na te- 
mat piękna w architekturze mają zbyt dużą wartość, by przypisywać im jakiekolwiek punkty. Są one trwałym świadectwem siły ludzkiego ducha, wydobywającej z przestrzeni przemijających zjawisk te spośród nich, które są warte uwiecznienia, i petryfikującej je dla kolejnych pokoleń, aby stały się dla nich nieustającą inspiracją i źródłem twórczego spełnienia.

Information about Author:

HENRYK BENISZ, professor, DSc, Institute of Philosophy, University of Opole; adress for correspondence: Instytut Filozofii Uniwersytetu Opolskiego, ul. Katowicka 89, PL 45-061 Opole; e-mail: benisz@uni.opole.pl 